\title{
The public as social experience
}

Samuel Mateus*

\begin{abstract}
What the concept of public means today? We seek to contribute to this debate searching for a third-way of appraisal: the public is neither a simple audience constituted by media consumers nor just a rational-critical agency of a Public Sphere. We argue the concept should also be seen in at the light of a publicness principle, beyond a critic and manipulative publicity.

In accordance, the public may be regarded as the result of the social activities made by individuals sharing symbolic representations and common emotions in publicness. Seen with lower-case, the concept is a set of subjectivities who look publicly for a feeling of belonging. So, in this perspective, the public is still a fundamental notion to social life although in a different manner in comparison to $18^{\text {th }}$ century Public Sphere's Public. He means above all the social textures and configurations where successive layers of social experience are built up. The public is, thus, acknowledged with the casual and spontaneous public communities disseminated through society carrying out processes of communication that use media to obtain a worldwide relevance.
\end{abstract}

Keywords: public, publicness, publicity, public sphere, social experience.

\section{The public as social experience ${ }^{1}$}

What may the Public mean? In a time where the concept seems so elusive, what is its significance to contemporary social theory? The Public is today a difficult notion to grasp giving its so many forms, types and appearances. It is often associated with Mass Communication, Mass Media and Mass Society. In this sense, it is often pictured as an audience: an assembly of media addressees (viewers, listeners, spectators) who compose

\footnotetext{
* Doutorando em Ciências da Comunicação - FCSH- Universidade Nova de Lisboa Bolseiro da Fundação para a Ciência e Tecnologia (sammateu@gmail.com).

1 This is a modified version of the paper presented at the $9^{\text {th }}$ Conference of European Sociological Association entitled The Public of Publicness, September 2009.
} 
a more or less homogeny social group and engaging in the reception of certain cultural products. For instance, audience is referred in German as Publikum, in French as publicl publique, and in Greek as teletheates. Because of this terminology's assimilation, many of the historical researches on the Public have been focused on the social reception of media products and in the ways people received and evaluated its contents. Publics had recurrently been studied as quantifiable standards that could be reduced to statistical survey and market research. These enquiries tried to make sense of the significations and effects of the cultural industry considering Publics as scientific objects to whom causal determinations could be attributed. Based on these assumptions, Publics are frequently reduced to their cultural objects having its particular identity deduced from them (Esquenazi, 2003: 9-17). Being a Public denotes, in this case, the ability to relate a cultural work to its author. The Public's reception process is determined by a sense of communion made possible by a common tribute. The author is the cohesion factor that underlies some Publics, as testified by fan communities or clubs. But in other situations is the very product the origin of a Public identity, like for example, the associations based on a car's or TV show's veneration. In this Public-Audience, the cultural reception of Publics would be structured by a complex of dynamic and polemic social interpretations shared by its member's media consumption (cf. Wolton, 1994: 69).

Still, is this connection between Public and audiences a promising one? Is the Public an audience? From an ethically point of view, it is impossible to perform such a reduction. The Public is that critical, rational and deliberative instance of the Public Sphere in which citizens question and ponder opinions in order to obtain a collective consensus on social and political matters (Habermas, 1991: 27). The audience being nothing more than a collective noun referring to the individualized reception of media contents. According to the Habermasian Public Sphere theory, nothing is more divergent: one being active, rational, critic and political, the other being passive, irrational, isolated and apolitical. A Public intrinsically eliminates any condition of becoming an audience; as long as it becomes massified and treated like a cluster of simple media consumers, he ceases to be a Public. Consequently the Public and the audience are to be described as autonomous concepts that are not to be mingled ${ }^{2}$.

\section{The capital public}

The most influential conception and chief understanding of the Public is based in the conceptual model of the $18^{\text {th }}$ century French, British and German Political Public Spheres (Habermas, 1991).

Facing the concept as a Public of the Public Sphere denotes, above all, a Public in capital letters, a collective subjectivity as the standard that determines the moral value of social and political action. The product of Public's discussion, critique and debate

\footnotetext{
2 In this perspective see Gitlin, Todd, Contra as Audiências (2006) In Abrantes José Carlos, Dayan, Daniel (org.), Televisão: das audiências aos públicos, Lisboa, Livros Horizonte, pp. 101-111. In this paper, Gitlin argues for the fictional nature of audiences highlighting how this notion turned to an useful tool to media industries to catalog its consumers. The bottom-line, it seems to us, is a clear separation between audience and Public.
} 
is Public Opinion which is invested with a superior moral authority on public issues and having a relevant binding power. In this appraisal, the Public may be regarded as a political voice demanding universal acceptation.

We may well spot a risk in this attempt to build the Public as a collective subject. Raising a universal and rational Public implies an impersonal, abstract and aloof configuration. When all individuality is subsumed in the collective subject, when singularities are wiped out, when a formal and rational argumentation replaces the spontaneous discourse, the Public tend to be transformed in a nebulous entity. From the abundance of criticisms attributed to the Public, we chose three authors representative of three important historical periods: 19 th, early $20^{\text {th }}$ and late $20^{\text {th }}$ centuries. Despite the temporal gap between them, they all give emphasis to the false uniformity that Public Sphere's conception of the Public stands for.

In 1846, Sören Kierkegaard wrote a literary review of the novel Two Ages authored by the Baroness Gyllembourg-Ehrensvärd in which he makes several remarks about the nature of the present age and its passionless and unresponsiveness attitude towards life. The Danish philosopher detects the tendency to equality and leveling, while stressing the conformity and assimilation of diverse individuals to an indifferent Public that kept apart their variety and distinctiveness. Public's tendency to rationalize with its incidence in reflection is considered decadent. According to Kierkegaard, the present age is one of indecisive deliberation and contemplation in which individuals do not have the strength to break the coils and seductive ambiguities of Reflection. Corresponding to l'esprit $d u$ temps in which the category of "generation" supersedes the category of the "individual" in order to level everyone and everything, the Public is the very instrument to that objective. " In order for levelling really to occur, first it is necessary to bring a phantom into existence, a spirit of levelling, a huge abstraction, an all-embracing something that is nothing, an illusion - the phantom of the public... The public is the real Levelling-Master, rather than the leveler itself, for leveling is done by something, and the public is a huge nothing" (Kierkegaard, 2001). He continues to stress Public's ambiguities distinguishing it as a desert and an empty entity fluctuating between everything and nothing. "The public is not a people, it is not a generation, it is not simultaneity, it is not a community, it is not a society, it is not an association, it is not those particular men over there, because all these exist because they are concrete and real; however, no single individual who belongs to the public has any real commitment" (Kierkgaard, 2001).

It is interesting to note that these general trends of analysis will be pursued in the critic of the Public in the next century. Walter Lippmann will, in 1925, continue the censure already present in Kierkegaard, arguing that the Public exists merely as myth and an idealization and therefore, is a Phantom-Public. Examining the democratic system, he rejects the classical assumption that the Public is made of sovereign, competent and capable citizens. The Public is, instead, a fiction embedded in false presuppositions. Most of the time, it is a mere political and social bystander (Lippmann, 1993). This Public's negative view were already present in its 1922 Public Opinion where Lippmann holds that the Public Opinion is controlled and that is a major fact contributing to the 
manufacture of consent as individuals show an inability to separate fiction from reality, the truth and the false, the unadulterated and the simulated (Lippmann, 2004: 19). Although there are some disputable statements, Lippmann has the merit to underline some hindrances to the claims of a solid, effective and powerful Public. Indeed, it supplies the abstract, irrational and leveller dimensions it has been accused of, in many aspects resembling an acritical gathering. For instance, he underscores how the individuals as a Public must primarily buy its own information and assumptions from media producers and rely in its accuracy and impartiality. It signifies more an act of passive media reception, than a critical, proactive and educated opinion formation.

Pierre Bourdieu also wrote on the abstract aspect of the Public, mentioned by Kierkegaard and implicit in Lippmann, referring to the Public Opinion pollings. Even if he is referring specifically to the statistical and quantitative form of Public Opinion, we can use its arguments to further enquire the conception of the Public. Bourdieu's considerations highlight three major contestations which lead him to declare that Public Opinion does not exist (Bourdieu, 1984), each one providing a useful insight to the Public's problems. The discussion of public sphere's Public naively supposes, for him, that every member of it encompass a firm and distinct opinion about every issue. Yet, it is not reasonable to assume that for each public question, each individual have a well-informed judgment or opinion about it. In addition, the Public Opinion takes for granted that Public's members have the time and the necessary means and effort to become familiar with the aspects involved in the debated issues. Another major problem of the traditional Public's perspective identified by Bourdieu is that Public Opinion posits the same importance to every opinion discussed. Nevertheless, we know discourse is never stripped of its social status or symbolic force. An expert's opinion hardly has the same weight than a common opinion. And a public personality's testimony has tremendous influence in shaping people's social perception, as exemplified by advertising campaigns. Last but not least, the French sociologist remembers us the Public has a propensity to forget how the apparent consensus Public Opinion exhibits is reached through an ardent, vigorous and enthusiastic dissensions. Even if a majority of opinions is attained, that must not palm off the intrinsic conflict that lies beneath it. The unanimity is always a social concession, a compromise generally accepted but that never reflects all segments involved. Opinions are, above all, contentious relations fighting for pre-eminence and recognition.

In this scenery, the capital Public, characteristic of the Public Sphere theory, is surrounded by suspicion, doubt and mistrust. We did not obviously intend to discredit the conception of the capital Public of the Public Sphere, but we wished to point out some of the feeblenesses it contains. Those weaknesses expose how such a conception is not anymore fit to the contemporary challenges societies face. We cannot only view in the concept of public its capital, critical-rational dimensions.

One way of dealing with the question about what the public is today consists to open a third path, away from the conception of an all-mighty powerful critical Public and away from the nihilistic and sceptical conception of it as an Audience. A path more humble and akin to the collective and individual experience of everyday social life: the 
public of publicness. This other possible design of the concept of public is characterized by its move from the political sphere to the sociological sphere where every social agent that engages in social interaction becomes a public agent. If we pay attention to publicness as an alternative to the conception of Public Sphere, we are obliged to assume a more eclectic social process that hinders the appropriation of morality by a single social group and the eventual strategy of consolidation of its interests. Unlike the capital Public who tries to fusion (in the public harmony of particular opinions), the public we are arguing for endeavours to fission; it is a layer of multiple and disputed social experience present in each social action.

Trying to contribute to the discussion of what the term public may today signify, we will argue that beyond a critical or a manipulative publicity there is also a publicness principle that attends to every human societies. It requires us to move outside the formal institutionalised political system and to take a closer look to the mundane social phenomena where people engage publicly with one another and with their society by a subtle and inconspicuous manner. Inside that publicness a public emerges as a shared identity and common apprehension of the world people have that runs through a collective conscience made visible and explicit by manifold symbolic materializations. Rendering a brief account of this other notion of public and unfold its role is what we intend to do next.

\section{Public: a possible understanding from the perspective of a publicness principle}

It is obvious, social analysis cannot afford giving up one such a notion like the public. In order to make it fit to contemporary challenges, the first thing we may do is to move from a too much static and institutionalized notion of Public Sphere or critical publicity to a more subtle and ubiquitous one, like publicness. Publicness is one of the most present regimes of social experience and contains the proper sense of the word: to publish is the action of making something collective and social. It embraces different behaviours and manifold manifestations: to print, to make visible, to distribute through the market, acess to the public forum, make visible or knowable, or establish something as a communal, shared and cooperative concern. Above all, approaching society from a publicness point of view corresponds to recognize the public not as a defined and fixed unit but a dynamic process of publication where people and issues become public as they are published and important to society. The public in not a pre-formed body but a work in progress where countless collective frictions and quarrels acquire an indisputable social relevance and are recognized as such. Thus, the public may be regarded, not as a fragment of the public sphere but as the publicness process all entire, made of small meanings in the empty spaces of social interactions. The public feels and experience together and sustains the public process. (Cefaï, Pasquier, 2003: 8). The capital Public is a rhetoric procedure searching a pragmatic effect to make visible the Public Opinion, the People or the Public Sphere. But the public (in lower-case) does not appear as an objective given or data. It emerges as a social texture changing in permanence as individuals distinguish spontaneously some issues as priority. It is an endemic category of symbolic processes practiced in daily life. 
From this publicness perspective, the public is one substratum of public action. The public is a collective actor appearing in chameleonic social scenery: that's why it has never ceased of reconfiguring itself through history: from the bourgeois living room, to the theater, through literary societies and clubs until more recent expressions consisting in a common feeling when a historical occurrence or ritual communion in front of a mediatised ceremony is publicly shared, (Dayan, Katz, 1996), or even the formation of face-to-face or virtual forums that some actors, musicians, TV series or videogames inspire and where a more or less rational debate is pursued. Current times had showed us that the public encloses composition modalities (mediatised, cultural, political) involving many competences, manifold engagements and multiple configurations. The public (in miniscule letters) appears like a fluid form of collective association that does not fall in entirely the Public Sphere's or audience paradigms; as an alternative, it shapes a plurality of people which gather more or less spontaneously, and having varied pretexts to experiencing a collective coexistence in a social world more and more exposed to egocentric individualism and the erosion of common values. Therefore, the public of publicness is a collective form of resistance giving proofs of a true resilience on the aim to preserve collective experience's textures: common memory, communications, cooperation, projection of joint horizons and meanings. And it does that spontaneously in vulgar and informal interactions where personal emotions and feelings replace the rationality and criticism as the main assets of the public.

What we are saying does not entail public judgment and discussion has completely disappeared but means, not only that the collective feeling and perception in the same spatial-temporal dimension accomplishes its pragmatic effect in a more subtle, familiar and casual way, as also it is pursued in the very different terrains and fields that the Public Sphere's Public model had difficult to enter. This new approach to the public addresses, more than concrete collective forms, the task of understand how layers of public experience are assembled in order to produce a coherent configuration. It is not tempted by public's reduction to a space or a sphere of communicational process. Even if the public is a form of communicative public experience, we should not restring it to the exclusive search of dialogic agreement and rational agonistic consensus (cf. Cefaï, Pasquier, 2003: 20). We find public understanding beyond deliberative processes because they do not subsume all symbolic processes. The formation of public issues is not restricted to inter-subjective procedures; they lie as well in complex mesh of practical actions anchored in symbolic dimensions less evident but so effective as rationality. Parallel to politics and hard-news media, runs an interactional logics implying a bigger spectrum of communicative and symbolic aims. Public discussion may as well be conducted in ritual ways without injuring possible compromises, polemics or transactions. In that case, the public may be, above all, a dispositive of social establishment of values, methods, rules and regulations authorizing a creation of a framework where people can collectively and spontaneously organize its social world.

This evanescence suggests a new conception: the public assumes a modality of experience where an aggregate people share collectively the same presuppositions and sensations about a social issue. But the central factor of public's definition, distinguishing it 
from the crowd, lies in its members have, in that particular moment or place, the same collective representations. While the crowd is defined by the similarity and physical proximity, the public established a more or less stable and durable bond between individuals, a common and mutual emotion (in Durkheim's sense). Hence, what is peculiar in the public is the synthesis of a general mental state possessed by all individuals. This means the current public signifies some sort of affective identity or social representation of personal feelings that enables positive and strong ties made possible by collective representations.

Therefore, public's authenticity may be possibly found in collective conscience and communities of life-experience (the Diltheyian Erlebnis) related with a projection of meaning in a particular social context. As Quéré explains: “A public must not be reduced to a positive facts' order: it does not match, for example, the group of individual gathered for a representations in any place during a given amount of time. It is a form and, as a form, it can just be apprehended by an act of understanding (to understand is to see emerge an organization and a global configuration)" (Quéré, 2003: 120). It is why Quéré sees the public as an intentional reality, that is to say, an order of meaning in which people feel, think, believe and act- have its sense of belonging- like they were one. The public is a social symbolic horizon from which springs individual's own singular beliefs and opinions, a mode of association that introduces a imaginative understanding that stresses what is to be considered socially relevant. It has a comissive quality (consider, for example, Austin's speech act theory), exhibiting a propensity to defend some values (and claim for others) while protecting its symbolic universe (Dayan, 2006: 32). It is this social horizon contained in the public that Hannah Arendt refers to when she means the public as the whole world, a world that interposes between men relating and separating them at the same time. For her, the public is that link among men putting them in relation that confers reality to the world (Arendt, 2001: 67-73).

The public of publicness may be an answer to those who vaticinate the end of a strong and capable Public. We suggest the public is very alive although it has to be viewed from another perspective. This is a perspective of an enlarged and unplanned sociability that social intercourse arises. This sociability is necessarily different from that concerned by Public Sphere (Habermas, 1991). It is not based in solidarity or obligation but in symbolic display, a space of heterogeneous and simple coexistence (cf. Weintraub, 1997: 16-27). As so the public must be seen at a different light: it does not designate a noun (the Public of the Public Sphere) but a mode of association in order to single individuals produce a collective action which can be better understood by an adverbial use. That is to say the public consists in mode of enlarged and everpresent sociability that is developed "in public". It is a always-changing and evanescent social group springing in public when its actions become published and enter publicness' domain. Between the formal and rigid Public held by public sphere's theory and the flexible and unprompted public of publicness lies the difference among its use as a noun or as an adverb. The latter may sometimes be confused with an adjective (a public occasion or a public theme) but is expresses preferentially a mode of social experience lived in conjunction in public, that is to say, the public indicates one modality of social 
communal experience. In this sense, as we have remarked, the figure of the public is not one and the same in every context: on the contrary, it is a configuration of social roles (Quéré, 2003: 131). Individual members of concrete social groups that change in roles according to the needs of each particular situation. It is the transformation of social experience that enables the transformation in the mode of association.

Viewed as an enlarged, rebel and adverbial sociability, the public must be open itself to include bigger portions of society for each single individual, as long as it is a social agent, it is also a potential public. We need to change the theoretical lenses and concentrate in other dimensions of the concept. Politically invisible but social effective, there is another aspect of the Public proving the existence of another conception of public expressing its vitality. See, for example, the 18th century pamphlets expressing the need of minor social classes being recognised publicly and being included in the social experience called the public (cf. Farge, 1992). Running parallel to the bourgeois Public, there are signs of a proletarian and plebeian public where singular and direct individual experiences are amassed and exigencies formally not recognised are expressed (cf. Negt, 2007). Seen as this other shady side of the capital Public- because it includes segments of society until now forgotten or repressed- the public we are accounting looks like a NonPublic (Esquenazi, 2004: 84). It is a form of association frequently disregarded and overlooked, sometimes silence but nevertheless eloquent that must be brought to discussion, not only to reception studies as also to study of the public. "If a no-public's community is capable of rationally justify its preferences and establish criteria and hierarchy, and also to publish its value judgements and making public its speech, it can constitute the core of a, inedited, still to come public" (Esquenazi, 2004: 97). While the capital Public pointed to a rational founded interpretation process, the lower-case public, points to an appropriation process where traditionally disregarded individuals integrate several problematic issues in their lives to apprehend it in a more idiosyncratic and concrete manner. It depicts a potential relation between the imaginative social representation of issues and an individual's subjectively lived experience. The foundation of this public's appropriations lies in an intense circulation between people's own life and the questions they face.

With this conception we have an open road to include in the public, for instance, the people who watch television and that assimilates the public issues contained in talk-shows, reality shows, soap-operas. Even it seems the two worlds are completely separated, there is a tenuous line between them that put the definition of the concept of public in a new unprecedented phase. It means television like other media could potentially become of source of publicness and presuppose, not just a mass-audience, but also a public, that is, a mode of social and symbolic association, based in its more emotional and entertainment contents. Hence, media can furnish reception frames that may activate another conception of what public may be, since they provide an important space and stock of public judgments. So, according to Esquenazi (2004: 93-94), and in what television concerns, this nonpublic posits three characteristics: the accordance between personal time and the time some contents are transmitted (people arrange its agenda accordingly); the formation of an ad-hoc community enabling opinion and commen- 
tary formation; and intensification of emotional ties people have with the Television program. The latter feature encourages and intensifies the sentiment of pertaining to a imagined community that induce a direct, face-to-face sociability (as, for example, fan clubs organise events to maintain and reproduce its identity).

Thus, unlike what Habermas argued in the The Structural Transformation of the Public Sphere (1991: 169), the conception of public we hypothesize may be founded in individual's media appropriation. And it shows as, one, a strong sense of belonging where people celebrate its collective identities; two, a rehabilitation of specific meshes of sociability; three, an impetus to defend its community as a separate and singular distinguishing it from other public communities (cf. Dayan, 2006: 38-39). It is a more ephemeral public but nevertheless a public since it is a form of collective experience with a strong sense of communal identity. Only from a Public Sphere's theory's point of view this new form of public is an almost-public (Dayan, 2006: 47). Because, given its strong sense of community and sociability, these belonging-charged collectivities can be described as true and essential publics. Although lacking the rational-critical attributes and focusing in general social issues that do not have a direct and more conventional connection with the political sphere or citizenship, this conception of public is nonetheless a form of social and collective experience centred in a dense sociability - even if sporadic or fluid. From its discussion does not necessarily follow an interpretation, or an intellectual and formal analytic exercise, but an appropriation, that is, the public discussion entails a personal assimilation that will form the basis to a public understanding of social issues.

We need move further to emotional aspects of the public sentiment included in the public from a publicness point of view. We all know that modernity had always paid special attention to man as a rational and logic creature. Nietzsche has regretted Socrates' heritage maintaining in The Birth of Tragedy that a natural creativity could only be achieved by a return to the primordial myth replacing Apollo by Dionysus. Like Nietzsche, Dostoevsky's too portrays modern man as unable to feel spontaneously. For instance, in Notes from the Underground the protagonist overrides natural feelings and emotions by a strong emphasis in human reason. And in Suicide Durkheim sees the intelligent and logical neurasthenic as the main applicant for a suicidal man. Yet, in hyper-modern times emotions are returning to the center stage (cf. Mestrovic, 1997). In part this is due to a demolition between private and public frontiers. We see an invasion by emotional aspects of personal life that in the past were simply rejected and pushed to the private domain. Personal feelings become public themes of discussion as expert discourses lose relevance to singular and idiosyncratic first-person speeches. There arises a popular discourse focused in everyday's life stressing social relations between individuals (Mehl, 1996: 168). Political and economical issues continue to be publicly debated but now they possess a more charismatic and expressive dimension. In this sense of publicness, the word of common and private people- as well as personal testimonies and vulgar experiences- is valued along with the specialist opinion. The public we are trying to describe here may be identified with this permeability in the public-private boundary of contemporary publicness. 
To an enlightened conception of Public, emotion is depicted as a negative aspect preventing individuals of being directed to serious matters. It is a huge obstacle to logical debate blocking enquiry and reasonable thinking. But facing the public as enlarged sociability and modality of social experience take us to realize how emotions of the private realm may affect society and its publicness in a mutual direction and dialectical process: from the individual to society but also from society to the individual. To feel implicated does not depend on a Public Sphere but on a more ingrained identification and appropriation of the problems of everyday life. Since a sense of publicness arises, media programs may implicate people on the evaluation of social, political and economic issues. Emotional processes of sympathy, empathy or even antipathy are capable of being shared and is such social sharing that publicness and the constitution of publics is all about. To question, to reflect, to take position, to participate means a public activity but is also an emotional act through which people share social experiences and organize its collective identity. It may also be emotionally-charged beyond of rationally and critically-charged. Reason is not the only way to achieve reflection and thinking: emotions too can attain it ${ }^{3}$. Sentiments and actions are apprehended as they are being experienced. Parallel to deliberation and persuasion there is a fusion and enthusiasm logics, where people not only are informed as also recognize what is at stake. Understand the public as social experience stresses the emotional aspects of public debate. The contemporary public is not just based in a modern rational tradition where knowledge and elite expertise prevails, but it is based as well in popular discourses and common-sense.

This emotional-charged public is recognizable when we consider some television programs whose distinctive trait is precisely the opportunity of first-person experiences to be published and to compose a common basis to apprehend public concerns, social and political issues. French Bas les Masques or L'Amour en Danger, Portuguese Você na TV, Sociedade Civil, Saúde Pública, German Fliege or American Oprah or Dr Phil are examples of television programs where several questions are debated that go from morals, politics, health and well-being, education and economy to justice, management, innovation and technology or leisure themes. There is a panoply of issues publicy debated where common people are invited to share their life experience, their fears, anxieties, as well their joys and achievements. In this casual publicness, a new meaning to public debate is being made. People who watch it (and they are millions throughout the world) form a public because they have emotional affinities to that discussion identifying themselves with the doubts and uncertainties of the guests. Is this way, the public discussion depends on a more emotional, direct and personal configuration. The problems concerning society are discussed in this public forum even though they are not developed in a rational but, manly, in an emotional manner. Themes like homosexuality, alcoholism, prostitution, professional harassment, bullying, unemployment, economic recession and inflation, conjugal problems, and so forth are publicly debated in this publicness enabled by television programs. Even more serious and exigent programs such as Portuguese Praça Pública or Opinião Pública invite people, as citizens but also, 
for instance, as sports fan, to published its own opinion, not by arguing logically but by relating less rhetorically its life-experiences. These television programs prove not only the public still exists (though in a very different form) as also proves that media can moderate and organize public forums where a public can be formed. Television programs, not all but some of them, have become more centered in common people questioning the traditional assumption about the public and its publicness. More than to argument, people testify. "The television of intimacy relates in a very specific way with society's debates. Valuing the profane word, it participates defies the expertise, erudite discourse and the traditional pedagogical posture. Accentuating experience's emotional dimensions, it contributes to an apprenticeship based, not in knowledge's rationality but in life's lessons" (Mehl, 1996: 193). Television makes the public discussion more visible. Demonstration has surrendered to presentation.

What is then the public of publicness? Is it a nonpublic? Or just a pretention to a Public, namely an almost-public? Well, in this paper we wanted to suggest the public may be understood as a social experience. So, it is a full-right public that does not stand between an inferior or a similar public. As a strong sense of publicness continues to live in contemporary societies, the public is a mental or physical gathering in which its members, despite their differences, share some intellectual and emotional affinities entering in a symbolic process of sociability. They have a collective identity and are still able to take positions on public matters even though in a more personal and confessional manner. The public is, thus, an enlarged association happening in public about public affairs and public pondering. It is not mainly an abstract entity or a noun, but an adverbial form of evanescent social experience. The public quality of social gatherings (mediatiased or not) is only given by its collective conscience and social relevant essence. It is not an attribute previous to its happening. Individuals become instantaneously a public wherever and whenever social experience is at stake.

Lisbon, January 2011

\section{Bibliography}

Arendt, H. (2001) A Condição Humana, Lisboa: Relógio d’Água.

Bourdieu, P. (1984) 'L'Opinion publique n'existe pas' in Questions de sociologie, Paris, Les Éditions de Minuit: 1984, pp. 222-235.

Cefaï, D.; Pasquier, D. (dir.) (2003) Les Sens du public - Publics politiques et publics médiatiques, Paris: Presses Universitaires de France.

Dayan, D.; Katz, E. (1996) La Télévision cérémonielle: anthropologie et histoire en direct, Paris: Presses Universitaires de France.

Dayan, D. (2006) ‘Televisão: o quase-público’ in Abrantes, José Carlos; Dayan, Daniel (org.), Televisão: Das audiências aos públicos, Lisboa: Livros Horizonte, 2006, pp. 29-49.

Esquenazi, J.-P. (2003) Sociologie des publics, Paris: Éditions La Découverte.

Esquenazi, J.-P. (2004) 'Structure du champ de la réception : publics et non-publics' in Ancel, P.; Pessin, A. (dir.), Les Non-publics - les arts en réception, Tome I, Paris: L'Harmattan, 2004, pp. 83-99.

Farge, A. (1992) Dire et mal dire - l'opinion publique au XVIII siècle, Paris: Seuil.

Habermas, J. (1991) The Structural Transformation of the Public Sphere, Cambridge, Massachusetts: MIT Press. 
Kierkegaard, S. (2001) 'A Literary Review', London, Penguin Classics - excerpt accessed in http://www.wsu. edu:8080/ dee/MODERN/PRESENT.HTM, in January 2011.

Lippman, W. (1993) The Phantom-Public, New York: Transaction Publishers.

Lippman, W. (2004) Public Opinion, Mineola, New York: Dover Publications.

Mehl, D. (1996) La Télévision de l'intimité, Paris: Seuil.

Mestrovic, S. (1997) Postemotional Society, London: Sage.

Negt, O. (2007) L'Espace public oppositionnel, Paris: Payot.

Quéré, L. (2003) 'Le Public comme forme et comme modalité d'éxpérience' in Cefaï, D.; Pasquier, D. (dir.) Les Sens du public - publics politiques et publics médiatiques, Paris, Presses Universitaires de France, 2003, pp. 113-134.

Weintraub, J. (1997) 'The Theory and Politics of the Public/Private Distinction' in Weintraub, J. and Kumar K. (ed.) (1997) Public and Private in Thought and Practice - Perspectives on a grand dichotomy, Chicago \& London: The University of Chicago Press, pp. 1-42.

Wolton, D. (1994) Elogio do Grande Público - Uma teoria crítica da televisão, Porto: Edições Asa. 